\title{
The Effect of Preschool English Education on Primary English Teaching
}

\author{
Wang Yadong \\ NanChang Institute of Science \& Technology
}

\begin{abstract}
With the increasingly deepening trend of internationalization, the importance of English education has also become more and more obvious. English study among low ages seems to be popular; however, it hasn't reached a consensus on whether it is appropriate for infants to study English in kindergarten or not. In China, English study begins in grade 3 in primary school prescribed by Ministry of Education, so there will be two-year gap if infants receive English teaching in kindergarten. Under this circumstance, shall we continue to keep the preschool English education? Is it effective for students to learn English since before primary school? Empirical ways are adopted in this paper to verify the constant effect of preschool education in primary school so as to discuss the feasibility of preschool English education from the perspective of effect.
\end{abstract}

Keywords-preschool; English education; study interest

\section{INTRODUCTION}

With the constant deepening of reform and opening up and increasingly wider international exchanges, English, as an internationally common language, has become an important tool for talents to connect the outside the world and conduct international exchanges and cooperation. The increasingly obvious importance of English has made English a hot social issue with constant attention.

The trend of a younger age for English learning has received wide attention from the public, especially in the circles of English linguistics and preschool education. Whether to conduct preschool English education is remaining under the dispute. Those who advocate preschool education believe that the preschool period is a key period for foreign-language study according to brain science, linguistics and learning psychology, so preschool foreign-language education is feasible; while those who oppose preschool English education think that the realistic environment for language learning is insufficient and the infants' psychology for study is immature. They don't think infants can learn two different languages well at the same time. The two sides haven't reached an agreement since they both seem to be logical.

In this paper, by comparing two kinds of children who have received preschool English education and who haven't received preschool English education in terms of their learning interest and learning performance in primary school, the author tries to find the differences between the two groups so as to judge whether preschool English education plays a role in students' performance in primary school or not. The study in this paper can enrich the feasible study on preschool English education, which can provide references for kindergartens and parents.

\section{THE EFFECT OF PRESCHOOL ENGLISH EDUCATION ON ELEMENTARY STUDENTS' LEARNING INTEREST OF \\ ENGLISH}

The time of English education in kindergartens, outside English training institutes and families are taken as independent variables, pupils' learning performance is seen as dependent variable, and students' genders, ages, time of education in grade one and grade two in primary schools (Education time of school English class, English training institute and family education) and family backgrounds (including parents' literary level and family income) are regarded as concomitant variables, and then covariation is adopted to make analysis.

According to the study, whether to receive preschool education or not has no significant effect on pupils' learning performance but has some negative effect on learning interest, which mainly manifests in the pleasure 
of study. Pupils without preschool English education have more pleasure in study compared to those who have received English education before.

Whether receive preschool English education in kindergartens or training institutes or not has no significant effect on pupils' learning performance, but the time of family education plays an significant role in pupils' learning performance. Pupils without family English education before primary school do better in their work compared to those who have received family English education. Pupils who received over 3 hours a week have better performance than pupils who received less than 2 hours.

The time of English education in training institutes as well as in families have no obvious effect on pupils' learning interest, but the education time in kindergartens can affect pupils' desire for knowledge. The longer the education time was, the lower desire for knowledge they would have.

\section{STUDY ON THE EFFECT OF PRESCHOOL ENGLISH} EDUCATION

Although it has become a reality to conduct preschool English education in the past few years, the teaching effect still needs to be verified. The infants with high-level English are more confident and concentrated with good planning and sense of achievement; besides, they do well in communication and cooperation with others; while infants with poor English level are less confident and distracted with much deficiency in cultural awareness, learning interest and motivation such as poor daily communication, listening and speaking. As far as learning interest is concerned, over 10 percent infants dislike English or consider English is useless. Even for the infants who like English, they are just praised by parents or impelled by some external motivations.

To sum up, it has received much importance from the academic world for feasibility of preschool English education, during which many scholars have proposed their own views, but there hasn't been a unified conclusion without persuasive empirical studies. In terms of the teaching effect, preschool English education may have certain effect on infants' learning style and learning attitude, but it has some other deficiencies. In general, there are few studies on the feasibility of educational effect of preschool English domestically as well as few following studies on the efficiency of preschool English education.

Suggestions for preschool English education

Foreign language education plays an important role in the integration of world economy as well as international competition since it is related to national development and promotion of national competitiveness. But should we lower the age for foreign language to preschool stage or even earlier blindly for its importance? Does the preschool stage fit for conducting English education? These problems are still under discussion among academic world without a unified conclusion. The effect of preschool English education may be difficult to last to elementary study after two-year gap, and it may even produce some negative effect since infants lack natural environment or motivations for English acquisition. Besides, the quality of preschool English education will also affect later study.

At present, preschool English education is very hot. Both kindergartens and outside training institutes want to gain some profits in the market. Therefore, many kindergartens or training institutes conduct preschool English education by boasting their abilities even though they may be unqualified. English education of poor quality or without any quality may produce negative effect on infants' learning interest in English study, and it can even cause learning obstacle. Thus, in my opinion, kindergartens as well as various training institutes should reflect on their own situations to avoid blind implementation of preschool English education.

\section{CONCLUSION}

According to my investigation, pupils whether have received preschool English education or not have no significance differences in learning performances and learning interests, and even pupils who haven't received preschool English education perform better than those who have received. Meanwhile, the time of receiving different types of preschool education have no significant effect on overall study. And even it may produce certain negative effect on pupils' expansion of learning interests after receiving family English education and kindergarten English education. 
According to China's actual situation, it is proper for our country to conduct English education from grade three (at the age of 9 or 10) since kids under this age have completed their acquisition of mother language basically with relatively strong logic thinking, which provides sound basis for foreign language study. At the same time, compared to teenagers, they also have advantages for foreign language study physically since their brain still can be shaped. In the future, after study in high school and universities, they may reach a higher level of foreign language.

\section{REFERENCES}

[1] Huang, Li Shih. "Success in English teaching." Canadian Journal of Applied Linguistics (2010)

[2] Martin. (1996). English teaching and learning in china Language Teaching, 29(29), 61-80.

[3] Milton, James. "Internet for English Teaching." System 29.3(2001):419-426.
[4] Pickering, Lucy, and C. Wiltshire. "Pitch Accent in Indian-English Teaching Discourse.." World Englishes 19.2(2000): 173-183(11).

[5] Charles M. Browne, and Minoru Wada. "Current Issues in High School English Teaching in Japan: An Exploratory Survey." Language Culture \& Curriculum 11.1(1998):97-112.

[6] Maum, Rosie. "Nonnative-English-Speaking Teachers in the English Teaching Profession." Eric Educational Reports December(2002).

[7] Cowan, J. R., Light, R. L., Mathews, B. E., \& Tucker, G. R. (1979). English teaching in china: a recent survey. Tesol Quarterly, 13(4), 465-482.

[8] Stewart, William A. "Urban Negro Speech: Sociolinguistic Factors Affecting English Teaching.." Florida F L Rep (1969):N/A.

[9] Chen-Chung, Yu. "Cultural Principles Underlying English Teaching in China.." Language Learning \& Communication 3(1984):1-92

[10] Hui-Qi, W. U., \& Ting, X. U. (2004). The application of multimedia technology in college english teaching. Journal of Xingyang Agricultural College, 605-610.

[11] Sarac H S. Benefits and Challenges of Using Second Life in English Teaching: Experts' Opinions[J]. Procedia - Social and Behavioral Sciences, 2014, 158:326-330.

[12] Liming amp Y U, Han J. Content-driven or Language-driven: Reflections on College English Teaching in Tertiary Education in China[J]. Foreign Languages \& Their Teaching, 2012. 